\title{
Business English Correspondence Characters and Role in foreign trade
}

\author{
Bin ZHANG \\ Jinan Vocational College \\ Jinan, 272200, China
}

\begin{abstract}
With the accelerating process of globalization, foreign trade has become an important criterion to judge whether a country can integrate with the world successfully, and it is a fast-track for a country to reach out to the world.In foreign trade, we need to do business communication with different countries and regions; we need the ability to communicate well with them depends on the mastery of business correspondence. Business English correspondence is a key medium for countries to do business dealings and establish cooperative relationship.This paper departures from the characteristics of Business English Correspondence, focusing its role in foreign trade.
\end{abstract}

Keywords- Business English Correspondence; Features; international trade; role

\section{INTRODUCTION}

English is the world's most practical and commonest language. In international business activities, the transfer of information generally in English predominantly, so it is known as business English. Business English is a product of economic globalization; it is distinguished for professional and specialized, different from ordinary everyday language.

Business English strives to use accurate specific simple and clear words. Business English Correspondence refers to the correspondence contacts using business English as the carrier in foreign trade activities. These correspondences including letters, e-mail, fax, telex and other means of communication, it is one of the primary means of international foreign trade activities in foreign exchange. Business English include a wide variety, according to the function, it can be divided into inquiry, reply letter, letter to negotiate, request letter, and contact letters, etc.

It runs throughout all the aspects of trading activities, playing a medium role in foreign trade activities.

\section{BUSINESS ENGLISH CORRESPONDENCES AND INTERNATIONAL TRADE}

In 21st century, with increasing economic interdependence of countries, international exchanges and economic interaction to communication has become the mainstream of world development. English as the world's most common language, it is a very flexible tool in international exchanges. English is the universal language in international communication, we called it Business English. Business English is the language commonly used in international trade, its unique style of language and communication skills occupy an important position in international trade and have a strong professional guidance.

In daily international trade, Business English correspondences do bilateral trade communication in English.

In international trade, the role of business correspondence has three main aspects of performance: First, information transfer; the second is to deal with relevant matters in international trade activities; the third is to promote communication between trading parties and emotional contact. There are lots of Business Correspondence communication ways, commonly used are letter, fax, telex, e-mail and other means. Correspondence international trade is a bridge between the two sides of trade, acting as a role of the media in international trade, so that a variety of business correspondence can be divided into inquiry letter, the offer letter, but also the disk letter, acceptance letter and so on. In the process of international trade business, according to its functionality, there are many different categories. In the form of different regions and countries, the daily life of the commodity exchange, labor export and technology exchange, commonly known as international trade, also known as the world's trade. Because of the complexity and diversity of international trade, there are different classification methods according to the different forms:

According to the transaction of trade, the content can be divided into goods trade, technology trade and trade in services; in international trade process, due to the different direction of the trade, it can be divided into the import trade, export trade, transit trade, net exports and net imports, reexport and re-import trade; in the transaction process, due to the different trading partners, it can be divided into direct trade, indirect trade and export trade; international trade process, subjected to geographical restrictions, leading different modes of transport, depending on the mode of transport, it can be divided into seaborne trade, trade by air, land and multi-modal trade transport and so on.

\section{INTERNATIONAL TRADE IMPLICATIONS AND FUNCTIONS}

International trade, also known as foreign import and export trade. It refers to the trading activities between a country or region and another country or regions, mainly goods, services and technology exchange activities. Types of foreign trade is various, according to the direction of the trade, it can be divided into the import trade, exports, net exports and net imports, re-export and re-import trade; according to the transaction object, it can be divided into 
direct trade, indirect trade and entrepot trade; in according to the mode of transport can be divided into seaborne trade, trade by land, air and multimodal trade; according to content, it can be divided into trade goods, trade in services and technology trade. Through foreign trade, not only can link the high level of developed countries, but also can promote the developing countries to join the ranks of foreign trade, thereby promoting economic development of the countries which have relatively low level of development and achieving mutual exchange of needed product between countries, optimal allocation of resources and better economic effectiveness. Meanwhile, foreign trade help countries to learn from each other and introduce more advanced science and technology, and absorb foreign scientific research, shorten the gap and enhance the country's economic strength, to better meet the competitive pressures and challenges of the international market.

\section{Business ENGLISH CORRESPONDENCE FUNCTIONS IN THE FIELD OF INTERNATIONAL TRADE}

With the accelerating process of international information and networked, we are brought into the information society.

The traditional means have been replaced by more efficient rapid, easy and convenient fax, Internet, e-mail and other means of communication. Business English with a smooth, complete, application and other characteristics, occupies an important position in the foreign trade, its purposes are to achieve more efficiently access to information, efficient communication, further strengthen business relations and harmonious trade relations. It has characteristics of highly efficient, economical and simple. In the operation of international trade, the business correspondence is an important legal basis. When trade disputes happen, the resolve of disputes depends largely on business correspondence.

International trade's dependence on exchange process documents is generally heated and business correspondence prominent role is more obvious. Currently, international trade covers three main areas in the WTO: trade in goods, trade in services and intellectual property trade. Business English, as a bridge of communicate information and channel of communication, has more and more important role in the three areas. The author, after some inquiry, put forward Business English capabilities in foreign trade: Business English Correspondence impacts on economic benefits of bilateral trade exchanges, even the success or failure of negotiations. So it requires our staffs to use the correct terminology and literary expression norms of foreign trade during import and export trade, especially the professionalism of our staff as well as English communication skills, writing ability plays a vital role in foreign trade exchanges, we must pay attention.

Business English correspondence's importance in services trade is reflected in the following areas: In international relations, we are mainly trade in goods, trade in services followed. In recent years, we have come into the stage which trades in goods and services are running neck and neck.
Since the 21 st century, the international trade comes into a new level; trade is service-oriented, trade in goods supplement. This is a historic turning point in international trade and a new level. From the point of the economic situation of the country whose international trade is frequently, the service trade in the development process of the entire international trade occupies an increasingly important position, and actively promote the liberalization of international trade. To further enhance the strength of China's international trade ability, it is necessary to expand the coverage of trade in services, accelerate our goods exportation, technology update, development of investment barrier-free and build an international trade big economic circle. Business English correspondence is an indispensable part to improve the economic benefits during the development of the trade in service. It is applied to the main aspects of trade in services include: advertising, business activities, translation services and so on.

\section{SUPERIORITIES OF BUSINESS ENGLISH IN FOREIGN TRADE}

The usage of business English correspondence placed the enterprises' activities in a virtual network platform. It has great advantages: it can speed up the communication between the two sides, break the geographical barriers and lead to the rapid sharing of the maximum amount of market information. It provides a new possibility to layout the allocation of world economy resources again. It can help companies to save huge transaction costs.

The dissemination of data, instead of the direct meeting between staff, can save communication costs and personnel costs. Network platform enables customers to communicate directly with the manufacturer, via email or fax. It can improve the quality of service and provide enterprise system in a fast and convenient way. Today, developed countries have begun to promote the usage of business English correspondence on the global scale during negotiating the import and export trade cooperation to achieve the duty-free treatment. This is a good start, it not only promoted the quantity of application of business English Correspondence but also promote the dissemination and usage of Business English correspondence on a global scale. It also greatly contributes to the development of information technology in the world and the world economic integration process.

\section{Business ENGLISH LANGUAGE FEATURES}

Business English is different from other style, it does not require too much words and rhetoric, but stress that the language should be concise, articulate, simple and succinct. Business English always be used in business dealings, having significant importance, which words must be accurate, specific, any mishandling may cause losses for company. Therefore, in order to avoid misunderstandings, Business English Correspondence should try to use the word which has clear meaning and avoid using the ague or ambiguous Words. Meanwhile, the Business English require to write decisively, use clear-cut attitude and outspoken. It can't 
appear hesitant, timid and ambiguous words. In addition, Business English

Correspondence often uses jargon, making the expression more concise. Business English correspondence always uses positive words and tone, focusing on the usage of courteous tone and confidence tone. So it can make the content easier for the other to accept.

\section{BUSINESS ENGLISH CORRESPONDENCE'S ROLE IN INTERNATIONAL TRADE}

In international trade, foreign enterprises due to time, space, language and culture barriers, can't often communicate and negotiate face to face like businesses in one country. After all, in a highly competitive international environment, time and cost plays an important role in the development of an enterprise. The traditional way of trade exchanges is tedious, time-consuming and laborious. So it is not conducive to trade and cooperate between countries, and hindered the progress of trade globalization. With the further development of the network, Business English correspondence effectively breaks the constraints of time and space, simplifies the process of trade activities, increases the speed of transactions, reduces transaction costs and promotes globalization trade implementation smoothly. With the timely communication carriers and media-- Business English Correspondence, it will become good fulcrums which make enterprises entry into the national market smoothly

With external trade activities increasing frequently, international exchanges are increasingly close, the number and size of international co-operation will gradually increase, thus effectively promote the development of the world economy and accelerate the process of trade globalization.

In modern international trade, Business English is not only one of the main channel for enterprises to access information, but also one of the tool for enterprises to save costs and improve efficiency. Compared with the traditional letters, used in international trade, Business English correspondence has many advantages: Business English Correspondence's storage is relatively simple, it is more easier to manage as an electronic document, and more conducive to manage the archive, therefore it can greatly reduce the workload and save work time; business English Correspondence can be classified easily, which will help to reduce the error-prone work areas, the chance of errors and the loss of business; business English Correspondence can be stored longer, so it is more conducive to store information of long-term customers and establish long-term effective linkages; timely transmission of information on Business English Correspondence can achieve timely communication and information feedback, while shortening the time to communicate information and reducing trade transaction costs. It has greatly improved the efficiency and reduced the cost of business.

In the increasingly competitive environment, through the medium of Business English Correspondence, enterprises can successfully expand their business globally, seek potential customers in the international market and cooperate with them; enterprises can also strengthen the contact with customer and establish strong cooperation and friendship by
Business English correspondence. Therefore, they can lay a solid foundation for exchanges and cooperation in the future.

\section{CONCLUSIONS}

With the development of international trade, business English correspondence also continues to develop and improve. From communication between enterprises to finally reach successful trade cooperation, Business English Correspondence plays a vital role in this process, determining whether they can achieve an agreement. Therefore, as a qualified foreign trade staff, they must first understand the characteristics of Business English Correspondence and then further understand its writing, only fully understand the importance of Business English Correspondence, they can be able to use of Business English Correspondence properly and reasonably to promote business development relationships with customers, reach new business and help enterprises improve efficiency, thereby gain a place in the international trade. Therefore, the role of Business English correspondence in international trade can be not ignored, meanwhile it also has a great space for development.

\section{References}

[1] Zhao Yan role of Business English in Foreign Trade [J] Chinese commerce, 2011,20: 234-235 + 237.

[2] Liyuan Hui Business English Correspondence role in foreign trade $[\mathrm{J}]$ Chinese commerce, 2010,16: 229-230.

[3] Zhang Wenli role Business English in Foreign Trade [J] Chinese commerce, 2010,26: 234-235.

[4] Wang Mei role of Business English in Foreign Trade [J] Chinese commerce, 2012,14: 241-242.

[5] Zhang Tingting Business English character and role in foreign trade [J] young writers, 2012,24: 184-185. 